\title{
Immigrant Representation in the Swedish Parliament: Towards Homogeneity or United Diversity?
}

\author{
Gunnhildur Lily Magnusdottir ${ }^{1}$ *
}

${ }^{1}$ Malmö University, Department of Global Political Studies, 20506 Malmö, Sweden.

\section{KEYWORDS}

Immigration

Intersectionality

Institutionalism

Descriptive and

substantive

representation

\section{A BSTRACT}

The current study explores how immigrants are represented within the two largest political parties in Sweden, the Social Democratic Party and the Moderate Party. Apart from exploring the descriptive representation of immigrants in the Swedish parliament, this article explores whether immigrant representation in the two parties in question results in visible diversity in views on immigration and in particular asylum politics. We are predominantly interested in exploring whether immigrant parliamentarians, who might have identities and experiences differing from the majority of the parliamentarians, represent views departing from the general party lines. The theoretical underpinnings of the article are based on an intersectionality approach and historical and feminist institutionalism, specifically the politics of presence, which explores the link between a critical mass in politics and critical acts or substantive representation. The first findings of the study, which have been reached primarily through a qualitative comparative analysis of survey material, are mixed. The number of Social Democratic and Moderate immigrant parliamentarians does not reach the level of foreign-born citizens in Sweden. Nevertheless, there appears to be room for diverse views on immigration and asylum politics that depart from the general party lines in both parties.

* Contact address: gunnhildur.lily.magnusdottir@mah.se (G.L. Magnusdottir) 


\section{Introduction}

Sweden has for decades been perceived as a humanitarian normentrepreneur, offering shelter to victims of war and political prosecutions. The country has also strived to act as an example-setter for other European states to follow, with its liberal immigration policy although recent border controls between Sweden ${ }^{1}$ and Denmark and a more restrictive asylum policy have now been implemented. Furthermore, Swedish citizens' views on immigration and ethnic minorities became increasingly positive in the past few decades (Eurobarometer 82 2014; Aylott and Bolin 2015). However, Sweden has also been confronted with structural and political integration challenges, increased polarization along with a growing support for radical right wing populism.

The current study primarily investigates how immigrants ${ }^{2}$, both women and men, are represented within the two largest political parties in the Swedish parliament, the Social Democratic party and the Moderate party. Apart from exploring how ethnicity, gender and cultural diversity are manifested in Swedish politics, we explore whether the views of female and male immigrant parliamentarians about immigration and asylum politics as well as gender politics appear to depart from the majority views within the respective parties, thus the general party lines. Based on own previous research on the link between equal descriptive gender representation and substantive gender representation in Scandinavian climate policy-making, the author is aware of that a critical mass or descriptive representation can be a blunt instrument not automatically resulting in critical acts, thus in a strong causal relationship between descriptive representation and substantive representation (Magnusdottir and Kronsell 2015). However further studies on immigrant representation and its effects are warranted as limited immigrant representation in democratic institutions might be

\footnotetext{
${ }^{1}$ In the autumn 2015 Sweden saw a massive increase in the flow of refugees seeking asylum in Sweden. This resulted in temporary border controls between Sweden and Denmark, intended to regulate the increased migration to the country from 1 $1^{\text {st }}$ of January 2016.

2 Immigrants are here defined as foreign-born individuals or individuals with foreignborn parents (second generation immigrants).
} 
considered a sign of a democratic deficit. Taking a starting point in Anne Phillips' $(2010,515)$ discussion on the politics of presence, this article claims that the representation of political ideas on immigration and immigrants' interests cannot be detached from the persons embodying that group. Consequently, the article aims to explore how immigrants, both women and men, are represented within the two parties in question and whether their views depart from the general party lines and if so, whether these views appear to be acknowledged or visible within the parties in question.

The article starts by mapping the descriptive representation of immigrants in the parliamentary parties in question in 2010 and 2014. Then it moves on to exploring the views of the Social Democratic and Moderate immigrant parliamentarians by scrutinizing survey material from the largest election compass in Sweden, the Swedish national television's (SVT) election compass $^{3}$ (valkompassen 2014). There candidates in the parliamentary elections 2014, including the current Social Democratic and Moderate parliamentarians, answered 45 questions in writing on different policy areas, such as: gender politics, immigration, health care, and education. The answers of the immigrant parliamentarians to these questions are then primarily compared to the answers of non-immigrant parliamentarians of these parties, in order to explore whether the immigrant parliamentarians represent different views and prioritizations within their parties. We also make a comparison between male and female parliamentarians, both immigrants and non-immigrants, in order to explore possible gender differences in the views on immigration and gender politics.

\section{The End of Bipolarity}

Swedish politics have in recent years been characterized by increased instability and changes in the political landscape. The era of strong Social

\footnotetext{
${ }^{3}$ The Election Compass 2014 was developed by the Swedish National Election Studies at the University of Gothenburg for the Swedish National Television (SVT).
} 
Democratic governments was broken in $2006^{4}$ when the centre-right government of the Moderate leader Fredrik Reinfeldt came into office. Reinfeldt and his government of 4 centre-right parties, The Moderates, The Centre Party, the Liberals and the Christian Democrats, was also the first majority government in Sweden for over a quarter of a century (Fredén 2014; Hagevi 2015; Aylott and Bolin 2015). However, in 2010, the traditional bipolarity of Swedish politics was shaken. Swedish voters used to have relatively clear choices between two blocks, one on the centre right with the Moderates in the forefront in recent years and the other on the left, led by the Social Democrats. When the right wing populist party, the Sweden Democrats (SD), won its first seats in parliamentary elections in 2010 the political landscape changed dramatically and had various consequences in Swedish politics and society. Firstly, Reinfeldt's centre-right government lost the majority it had gained in the elections of 2006, although the government slightly increased its vote share in 2010 and the Moderate Prime Minister became the first centre-right Prime Minister to retain office after parliamentary elections. The centre-right government could have maintained its majority in 2010 by including SD in its government but all four parties of the government alliance, along with the opposition parties, had made it clear that they would not form a government with SD due to SD's restrictive immigration policy (Hagevi 2015; Aylott and Bolin 2015). Second, the entrance of SD into the Swedish parliament, Riksdagen, was startling to many of the mainstream voters who perceived their entrance as a blow to both the Swedish identity and Sweden's reputation based on humanitarian activism and an all-inclusive welfare system (Sannerstedt 2014; Hellström 2013, 2010). Mainstream voters and media also raised questions about whether Swedish politics were moving away from the policy of multiculturalism and liberal asylum politics, closer to the neighbouring

\footnotetext{
4 From the 1930s until 2006 there was an almost unbroken era of Social Democratic governments in Sweden. The Social Democrats were in opposition only for nine years during that period. The Social Democrats won on average over 42 per cent in parliamentary elections between 1948-2002 (Allern and Aylott 2009).
} 
Nordic states with established populist parties and more stringent policies of assimilation (Allern and Karlsen 2013; Erlingsson, Loxbo and Öhrvall 2012).

The reactions of both the government alliance parties and the opposition parties to SD's entrance into Riksdagen were to some extent characterized by attempts to isolate the party in the parliament. Swedish media also exercised a similar isolation strategy against SD. Major newspapers and broadcasting companies denied SD access to advertisement space/time for the election campaign in 2010 and campaign articles written by members of SD were generally not published in mainstream media in 2010. This isolation strategy of both other parties and media did not have the intended effects but rather strengthened the identity of the party and their voters as outsiders and rebels against an ineffective establishment disconnected from the people. In the parliamentary elections of September 2014, the support for SD increased from 5.7\% (parliamentary elections 2010) to $12.9 \%$, making them the third largest party in Sweden (The Swedish election authority 2014). Furthermore, significant changes in attitudes towards the SD had also occurred between 2010 and 2014. Mainstream media now granted SD access both to advertisement space/time and published SD campaign articles, which had been nearly impossible for SD to obtain in 2010. Four years in parliament had to some extent normalized SD as an established party and the party was not as often referred to as the 'immigrant hostile' party in media as in the 2010 election debates (Eriksson 2016; Linderoth 2015; Sannerstedt 2014).

The results of the European Parliament (EP) elections in May 2014, where populist Eurosceptic parties on the right wing increased their vote share considerably, gave strong indications about the strength of SD at the national level. In 2014, SD also gained increased support from other social groups than in 2010, e.g. from urban voters with medium or high income and education, female voters, elderly voters and European immigrants (Sannerstedt 2014; SVT 2014a). Immigration was not however one of the top priorities of the median voter in 2014, who prioritized health care and school reforms. 
The responses of the other parties, both the centre-right government and the left opposition parties, between the EP elections in May and the Swedish parliamentary elections in September, were unfocused and they '...edged nervously around where they believed the median voter might be lurking...' (Aylott and Bolin 2015, 3). In this period, the Moderates continued to lose support, mostly to $\mathrm{SD}^{5}$, as the Sweden Democrats are otherwise considered to be a traditional centre-right party close to the Moderates in many other policy areas than immigration. However, less than a month before election day, Prime Minister Fredrik Reinfeldt shifted the focus to immigration after a prognosis from Swedish migration authorities, stating that as many as 80000 refugees were expected to seek asylum in Sweden in 2014 (The Swedish Migration Authority, July 2014). The Prime Minister stated that the high cost associated with this amount of asylum seekers would create tensions in Swedish society, but being a firm advocate of multiculturalism and liberal immigration politics, the Prime Minister also stated that he was '...asking the Swedish people to open their hearts for those vulnerable people who we see around the world' [author's own translation] (Rosén 2014).

These statements were criticized for emphasizing the financial cost of a liberal asylum policy and some also claimed that Prime Minister Reinfeldt had unintentionally strengthened SD by placing their prime topic higher on the agenda and by highlighting the aforementioned economic burdens.

It is difficult to say how much Prime Minister Reinfeldt's statements affected the final outcome of the elections. Still, immigration and asylum politics did not gain a permanent place at the top of the agenda, as mainstream voters continued to focus on their prior prioritizations, the health care system, education and employment ${ }^{6}$, according to surveys conducted in the last weeks before the elections (SVT 2014a; Novus 8/9

\footnotetext{
${ }^{5}$ Approximately $1 / 3$ of the voters that voted for SD in 2014 had voted the Moderate Party in 2010 (The Swedish Election Authority, SVT's election compass-SVT 2014a).

${ }^{6}$ Immigration did however become a top priority for Swedish voters in the autumn 2015 following an increased flow of (primarily Syrian) asylum-seekers to Sweden in 2015 (Svenska dagbladet 7.12.2016).
} 
2014). The results of the elections were not only a disappointment for the defeated centre-right alliance that had governed for the past eight years, but also for those that opposed SD. Furthermore, the new minority government of Social Democrats and Greens had (and still has) a narrow parliamentary base, with the support of the Left party (The Swedish Election Authority 2014).

Graph 1: The Swedish parliamentary elections 2014 and 2010

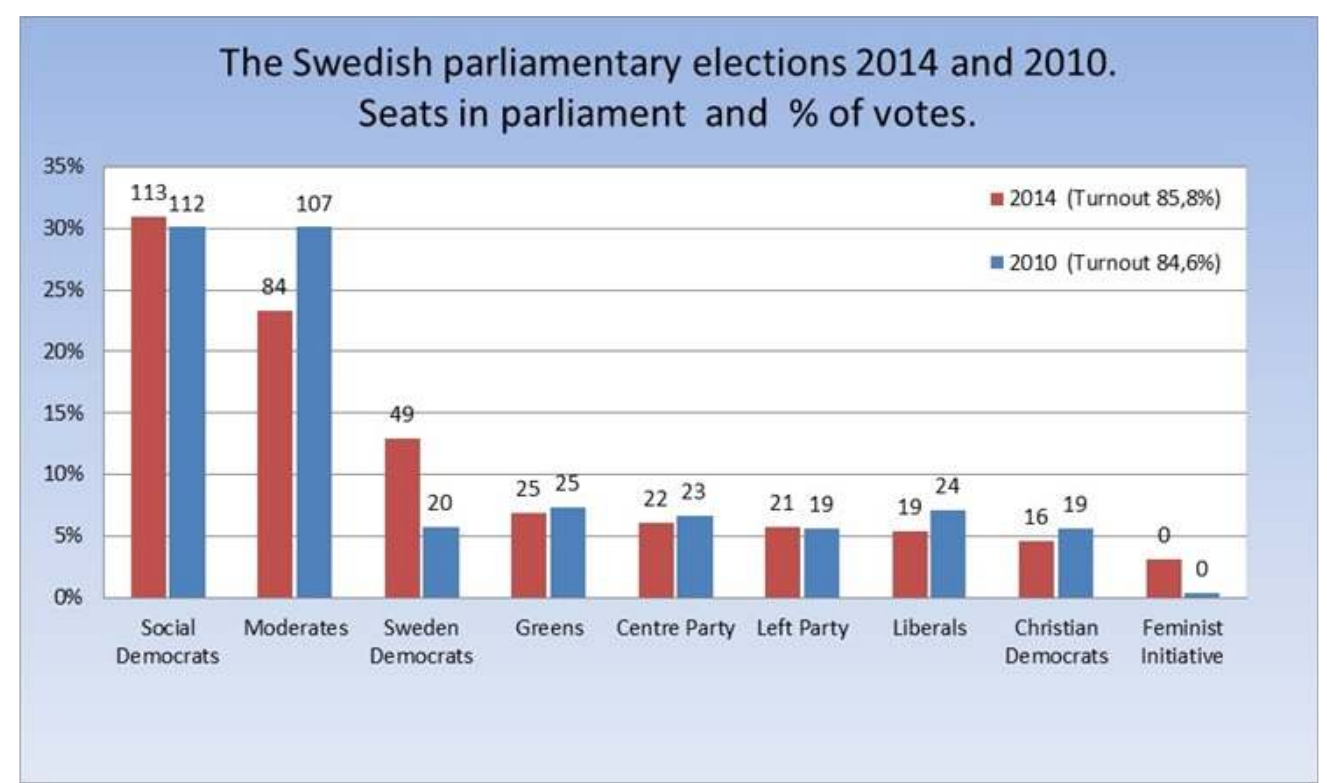

Source: The Swedish Election Authority/Valmyndigheten 2014

SD's strong position resulted in a government crisis in December 2014 when the government was unable to get its budget approved in the parliament. SD supported the budget proposal of the centre-right opposition although SD had previously announced that the party would vote against every government's budget unless their demands on a more restrictive migration policy were met. The Social Democratic Prime Minister, Stefan Löven, announced that extra elections ${ }^{7}$ would be held in March 2015 since the budget was not approved. The political climate was tense and the

\footnotetext{
7 These kinds of extra elections were last held in 1958 in Sweden.
} 
government and the centre-right alliance accused each other of a limited spirit of co-operation. The centre-right alliance was also accused of being a poor loser, taking advantage of the political instability caused by SD (SVT 2014b, DI 2014). Polls in December indicated that the Social Democrats would increase their vote share, the alliance parties, including the Moderate Party, would slightly decrease their vote share and that SD would increase its vote share (Novus 16/12 2014). The government and the centre-right alliance reached an agreement on the $2^{\text {th }}$ of December and the extra elections were cancelled (Aftonbladet 29.12 2014). Apparently both sides deemed it necessary to co-operate in order to secure a functioning minority government that was not dependent on SD support. Immigration thus made it indirectly to the top of the agenda again in late December, reminding Swedish voters of how politically sensitive migration politics can be.

\section{The Politics of Presence}

Research on descriptive representation in Western European political institutions has primarily focused on gender representation, with scant attention being paid to other intersecting factors such as ethnicity, class or education. The present article seeks inspiration and builds on feminist research on gender representation and expands relevant feminist scholarship to employ in the context of immigrant representation. Representation in politics, or the lack of representation, has been an important topic in gender studies and the women's movement since suffrage debates but it is also central to debates on democracy since concerns for representation, often indicate a democratic deficit or invisibility of certain groups in society (Lovenduski 2005, 1; Magnusdottir and Kronsell 2015, 5; see also Dahlerup 2006). Accordingly, if for example representation of different social groups or minorities is lacking or low in democratic institutions or the representation is not balanced then it could be perceived as a sign of ill-functioning democracy. 
There has been considerable debate over the years about the meaning of the concept of representation. Political theorists are inclined to use several different categories of representation (Mansbridge 2003, 520; Dahlerup 2006, 514). In our context, it is most relevant to distinguish between the aforementioned concepts of descriptive and substantive representation. The starting point is in the 'critical mass' argument, originally formulated within the business sector by Kanter (1977) who argued that a certain number of women needed be present for their presence to be felt (Dahlerup 2006, 515). Dahlerup (1988) further developed the critical mass concept for gender politics, suggesting that the number of women represented matters for representation to have substantive effects. Concepts like the critical mass can be useful and important not only when studying gender representation but also the presence of minority groups in politics. The critical mass concept can however become problematic when the focal point is on the numbers, without a thorough exploration of the possible effects of the representation, thus the critical acts. Anne Phillips $(2010,515)$ writes that to rely only on the representation of political ideas and views, for example through political parties, is not at all sufficient. She argues for a politics of presence and is weary of the notion that there can be a representation of ideas and views for example on gender that would be detached from the person who is representing. Accordingly, the politics of presence compel us to include ethnicity as a defining social factor in the current analysis of the immigrant representation.

Phillip's politics of presence has been developed into two main approaches, descriptive and substantive representation (Phillips 2010; Lovenduski 2011, 745). Descriptive representation concerns the number of women and men (or social groups) and the relationship and balance between different representatives in elected bodies and other political institutions. The share of seats in government, parliament and in the nomination, lists of political parties are commonly used as a way to indicate inclusion of women (Wängnerud 2009, 53) but can also be used to explore the representation of minority groups. Defining what substantive 
representation means is a more challenging task and the link between descriptive and substantive representation is to be considered more of a probability than a determined and empirically established fact (Magnusdottir and Kronsell 2015, 2016; Wängnerud 2009, 55).

One might suspect that a larger community of immigrant politicians and decision-makers would have substantive impacts by increasing democracy when these immigrant representatives become engaged in a range of policy activities that they were previously excluded from. However, the own previous studies on gender representation in Scandinavian climate policy units at the state level revealed that a genderbalanced descriptive representation was a blunt instrument that did not automatically lead to substantive gender representation (Magnusdottir and Kronsell 2015). While substantive representation centres on the impact or effect of balanced representation, another aspect of this is the assessment of whether immigrant representatives are in any way different from nonimmigrant representatives. Accordingly, representation is not merely about equal democratic rights but also about acknowledging that immigrant representatives may have different views and experiences that need to be presented and visualized as an important contribution to Swedish politics.

An interesting lesson to draw from gender politics is that Nordic gender quotas (mostly used in Norway and Iceland) are not merely perceived as a matter of democracy and social justice (Freidenvall and Krook 2010), but they are viewed as a tool to include women's experiences and views that differ from those of men (Magnusdottir and Kronsell 2016; Inhetveen 1999). This is highly relevant for the current study, although the Swedish political parties do not use any sort of formal quotas, since the experiences and views of different groups of immigrants may also differ from the majority of the Swedish people. Drawing parallels from studies on women's representation, which have measured the importance of gender in the parliamentary process and demonstrated that female representatives help strengthen the position of women in society, we assume that immigrant representatives in parliament may strengthen immigrants' position in 
society. However, inspired by feminist and historical institutionalism we also suspect that we might detect assimilation of views and what might be called 'homogeneous Swedishness' within the two political parties in question.

It is namely relevant to employ historical and feminist institutionalism in our analysis. Feminist institutionalism, which can be expanded to include other intersecting social factors than gender, argues that institutions are important to study because institutions organize power inequalities through formal as well as informal rules and practices and that constructions of identities are intertwined in the daily life or logic of institutions. Institutions, such as political parties, are arenas where social symbols such as ethnicity and gender are (re)shaped and individual identities can be products of institutions (Pierson 2004; Kenny 2007; Magnusdottir and Kronsell 2016).

Power relations built on ethnicity have previously been overlooked in institutional theory but this study builds on historical institutionalism, using its analytical strengths and concepts while seeking to overcome its blindness. The article therefore combines insights from historical institutionalism about 'path dependency' and the 'stickiness' of institutions with an expanded feminist institutionalism. Pierson says about power inequalities in institutions that they '...can be reinforced over time and often come to be deeply embedded in organizations and dominant modes of political action and understanding, as well as in institutional arrangements' (Pierson 2004, 11). Furthermore, path dependency in institutions, such as the political parties, can be understood as 'sticky' because opportunities for innovation and changes are constrained by previous choices (Kenny 2007, 93).

In our analysis, we are also inspired by the intersectionality approach although we do not employ it to the same extent as our main analytical tools, thus historical and feminist institutionalism. The idea that women have special interests and men others has been widely discussed as part of the debate on women's representation and it is with certain unease that the concept has been used. Anna Jónasdóttir $(1988,38)$ suggests that there is a 'minimal common denominator' in the shared interest of acting against the 
gender order. In later work, Jónasdóttir and Jones (2008, 9-10) argue convincingly for the relevance of the interest concept as useful for analysing gender. One problem in thinking in terms of interest, which is not taken up by these authors, is raised by Weldon $(2011,441)$. She says that the problem is not: '...that women never share any interests' but that a focus on interests and a tendency to conceptualize them as common ones, lend privilege to certain women. This can be expanded to our study as we suspect that welleducated, high income earning immigrant parliamentarians might have less in common with low-income, working class immigrants than with their fellow non-immigrant parliamentarians. Consequently, it may obscure minority views by overriding the differences that exist between immigrants in terms of experiences and social positions (Weldon 2011, 442; see also Nagel 2012).

\section{Methods and material}

The descriptive and substantive representation of immigration and gender are primarily explored by mapping immigrants in the Social Democratic and Moderate parliamentary parties in 2010 and 2014 via a qualitative analysis of the survey material from SVT's election compass. The study starts by comparing the descriptive representation of immigrant parliamentarians to the entire proportion of immigrant citizens in Sweden in order to establish how well immigrants are represented within the parliamentary parties in question. We also map the representation, of female and male immigrants in the Social Democratic and Moderate parliamentary parties and compare it to the general gender division in the parliamentary parties in question. Furthermore, we make use of relevant data in regards to education and age in order to deepen our understanding of influential intersectional factors, other than gender, ethnicity or origin.

Then we move on to exploring the views of immigrant parliamentarians by scrutinizing survey material from the largest election compass in Sweden; The Swedish national television's (SVT) election 
compass (valkompassen 2014), where candidates in the parliamentary elections 2014, including the current Social Democratic and Moderate parliamentarians answered 45 questions in writing in different policy areas; such as gender politics, immigration, health care and education. We have selected 8 out of the 45 questions, 6 questions discuss immigration politics and (all) 2 questions discuss gender politics. The answers of the immigrant parliamentarians to these questions are then compared to the answers of non-immigrant parliamentarians of these parties in order to explore whether the immigrant parliamentarians represent different views and prioritizations within their parties than the majority of the Moderate and Social democratic parliamentarians. We also make a comparison between male and female immigrant parliamentarians in order to explore possible gender differences in the views of the female and male immigrant parliamentarians.

\section{Descriptive representation of immigrants in the Social Democratic Party and the Moderate Party 2010-2014}

Our intention in this section is not to give a complete account of immigrants' involvement in Swedish politics but to map and discuss immigrant representation within the two largest parties in parliament as they are deemed well-suited to give us indications about descriptive representation of immigrants in Swedish politics. Definitions of immigrants have been a reoccurring theme in Swedish academic debate in recent years since these definitions are somewhat problematic and vague. In the current study, we have defined immigrants as foreign-born individuals (first generation) or individuals with two foreign-born parents (second generation immigrants). In 2014, approximately 7.5\% of eligible voters were foreign-born Swedish citizens and around $15.4 \%$ of the total population was foreign-born (The Swedish Statistical Authority 2014). These $15.4 \%$ foreign-born Swedish citizens (first generation) situate Sweden in the 10th place of the 34 OECD states in terms of the proportion of foreign-born citizens of total population (OECD 2014; The Swedish Statistical Authority 2014; The Swedish Migration 
Agency 2014). The numbers become considerably higher when second generation immigrants are included, well over 20\% (The Swedish Statistical Authority 2014). These numbers, especially those of second generation immigrants, are estimated, and these numbers are in general problematic as immigrants from the other Nordic states - Denmark, Norway, Finland and Iceland - are not included in these numbers and Finnish immigrants are one of the biggest immigrant groups in Sweden (The Swedish Migration Agency 2014). These numbers are still to be considered useful however for comparison when exploring the descriptive representation of immigrants in the Swedish parliament.

We start our mapping within the Social Democratic Party, which is currently the largest party with 113 parliamentarians or $31 \%$ of the seats in the parliament. A simple mapping reveals that $11.5 \%$ of the Social Democratic parliamentarians in 2014 are immigrants. Most of them are foreign-born themselves but a small minority are second-generation immigrants with foreign-born parents. The proportion of immigrant parliamentarians does therefore not reach the $15.4 \%$ foreign-born population but there is an increase from 2010, when the Social Democratic immigrant parliamentarians were only $8.03 \%$ of the parliamentary party. Women are $43 \%$ of the Social Democratic immigrant parliamentarians and men 57\% which is to be considered a gender-balanced representation. This is in line with the general gender division within the Social Democratic parliamentary party with $53 \%$ male parliamentarians and $47 \%$ female parliamentarians in 2014 (SVT 2014a; The Swedish Election Authority 2014). Approximately 66\% of the Social Democratic immigrant parliamentarians are originally from another EU state or from one of the EU candidate states, including Turkey. The rest are from states with a high number of refugees such as Iran, Syria and Eritrea. Accordingly, European immigrants appear to be overrepresented among Social Democratic parliamentarians as just about half of foreign-born citizens in Sweden are European (SVT 2014a; The Swedish Statistical Authority 2014). 
Graph 2: Foreign-born Swedish citizens 1960-2013

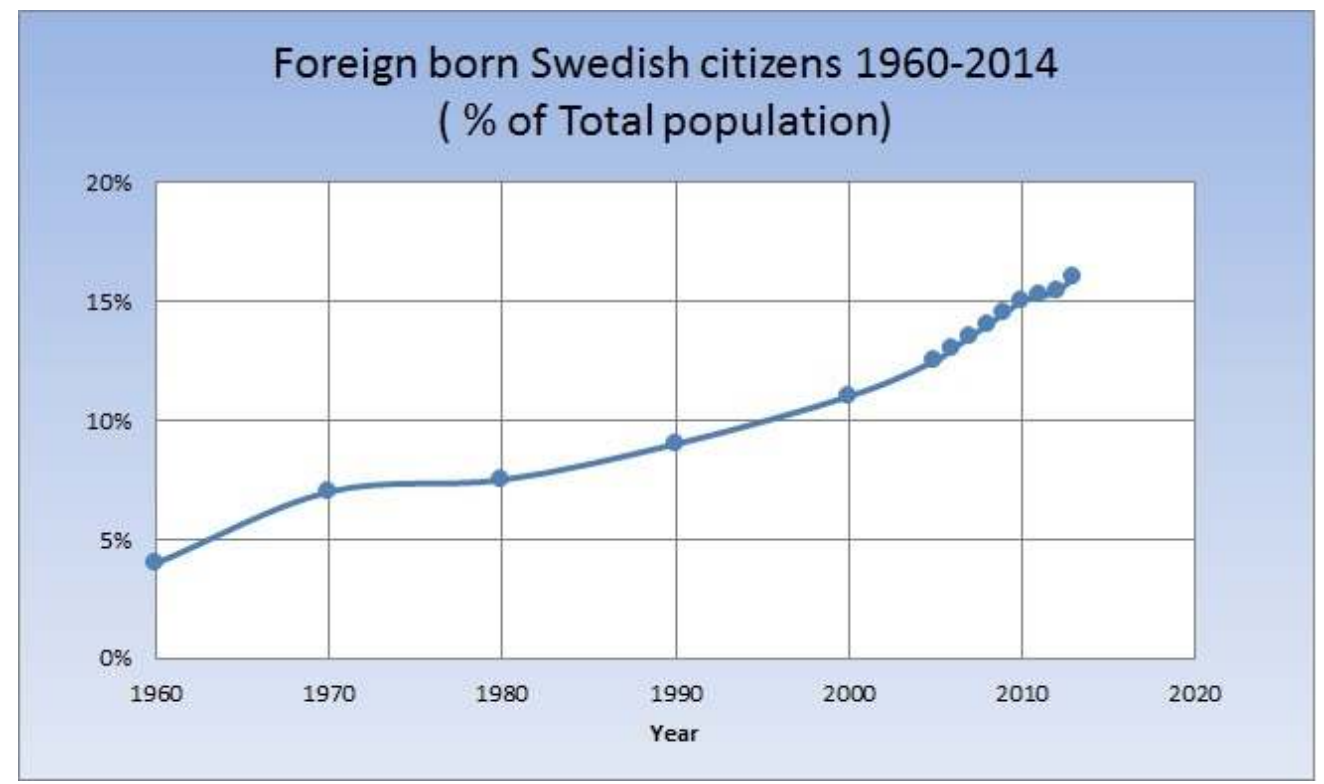

Source: The Swedish Statistical Authority 2014

We then move on to the Moderate Party, currently the second largest party with 83 seats or $23 \%$ in the parliament. In 2014, nearly $11 \%$ of the Moderate parliamentarians were immigrants. The percentage was almost identical in 2010, when the Moderates had 107 seats in the parliament, 11.2\% of their parliamentarians had an immigrant background in 2010. The proportion of Moderate immigrant parliamentarians does therefore not reach the $15.4 \%$ foreign-born population Women are $56 \%$ of the Moderate immigrant parliamentarians and men $44 \%$, which is to be considered a gender-balanced representation. This is in line with the general gender division within the Moderate parliamentary party with 52\% male parliamentarians and 48\% female parliamentarians in 2014 (The Swedish Election Authority 2014). The origin of the Moderate immigrant parliamentarians appears to be more balanced than in the Social Democratic party as $56 \%$ of the Moderate immigrant parliamentarians come from EU or EU candidate countries, including Turkey, and $44 \%$ from states outside of Europe. Accordingly, there appears to be a fairly balanced representation 
between EU immigrants and non-EU immigrants, although specific states with large refugee groups, such as from Syria, Afghanistan and Eritrea might be underrepresented (The Swedish Statistical Authority 2014; SVT 2014a). A vast majority of both the female and male immigrant parliamentarians in both parties has a university degree, which is in line with the general education level of Swedish parliamentarians and the fact that the general education level of Swedish immigrants is equal to the education level of ethnic Swedes (The Swedish Statistical Authority 2014).

\section{Concluding discussion: Towards a Homogeneous 'Swedishness' or United Diversity?}

We have now established the descriptive representation of immigrants in the Social Democratic party and the Moderate party in 2010-2014. Our first findings reveal that the percentage of immigrant parliamentarians, including second-generation immigrants, does not reach the same level as foreign-born citizens in Sweden, excluding second-generation immigrants. Nevertheless, the descriptive representation of immigrants has increased in the Social Democratic party, between 2010 and 2014, which might indicate further attempts to inclusion. Now we are interested in scrutinizing whether the descriptive representation of immigrant parliamentarians has led to any critical acts. More precisely, critical acts such as the recognition or visibility of diverse views, identities and experiences in party politics rather than political homogeneity. As a first step, we suggest that evidence of diversity acknowledgement is to be found in the answers of the parliamentarians in SVT's election compass 2014. Systematic comparison of the answers of the immigrant parliamentarians, both women and men and the non-immigrant parliamentarians reveal some diversity worth further exploration.

Starting with a general question on multiculturalism: all the immigrant parliamentarians from both parties claim that it is a very positive proposal to aim for a multicultural Sweden. This is slightly more positive than the general party lines in both parties. In the Moderate party, where 
$61 \%$ of the respondents are very positive and 29\% are rather positive and $2 \%$ are negative. Within the Social Democratic Party $86 \%$ are very positive and the rest are rather positive. In comparison $95 \%$ of the Sweden Democrats are very negative.

The five additional questions in the immigration category give rather mixed results. Those questions all indicate some sort of a diversity visibility within the political parties in question as the views of the immigrants differ from the views of non-immigrants but gender differences among the immigrant parliamentarians are barely visible. Female and male immigrant parliamentarians in both parties are for example all more negative than the general party lines, to the proposal of making it possible for asylum seekers to apply for an asylum at Swedish embassies abroad and the main argumentation appears to be concerns about that the principle of legal security might be compromised. The immigrant parliamentarians are also all more negative (very negative) towards the proposal of Sweden accepting fewer immigrants in the future. The differences between the immigrant parliamentarians and the general party lines are however very slim as the majority of both Social Democrats (98\%) and the Moderates (86\%) perceive this proposal as negative or very negative. In comparison $91 \%$ of the Sweden Democrats are rather positive or very positive towards this proposal.

Two questions/proposals out of the 6 questions/proposals regarding immigration politics, produce more surprising results, worth further investigation. First is the following proposal:

The police should actively search for asylum seekers whose asylum applications have been rejected and the police should deport them (SVT 2014a) [author's own translation].

All of the Social Democratic immigrant parliamentarians are rather negative towards this proposal, which is in accordance with the party line as $80 \%$ of the Social Democrats are rather negative or very negative here. The general party line for the Moderate party here is that $59 \%$ are rather positive or very positive but among the immigrant parliamentarians $75 \%$ are rather positive or very positive and the rest is negative but gender differences are not detected. 
A proposal/question for free healthcare for undocumented migrants also produces some interesting results for the Moderate Party. All of the Moderate immigrant parliamentarians are rather negative towards free healthcare for undocumented migrants, which is interesting since $28 \%$ of the non-immigrant parliamentarians are rather positive and $12 \%$ are very positive. The Social Democratic immigrant parliamentarians' answers are almost identical to the general party line where $55 \%$ are rather positive $(53 \%$ of general party) and the views of the rest of both immigrant parliamentarians and non-immigrant parliamentarians are distributed along similar patterns from very positive to rather negative or indifferent) with no detectable gender differences. In comparison, $97 \%$ of the Sweden Democrats are very negative towards providing free healthcare to undocumented migrants.

The results for the two last proposals/answers discussed are interesting, as the Moderate immigrant parliamentarians appear to be more negative than their non-immigrant colleagues. Feminist and historical institutionalism might provide us with partial answers about this stringent position of the Moderate immigrant parliamentarians. They might be experiencing some sort of a 'hegemonic Swedishness' within the Moderate party, where there is certain stickiness within the party as an institution and where ethnicity only refers to the immigrants. The immigrant parliamentarians might therefore feel pressured to assimilate to the majority views. This affects their potential role as possible protectors and advocates of undocumented migrants as well as other immigrants. The intersectionality approach might also apply here, as the immigrant parliamentarians might not have much in common with e.g. undocumented migrants. The parliamentarians are well-educated high-income earners. In addition, the immigrant parliamentarians that originally came as refugees were granted asylum and have most likely never lived in Sweden as undocumented migrants.

We detect a similar pattern when exploring standpoints on gender quotas in the private sector in SVT's election compass. Immigrant female parliamentarians in the Moderate party appear to be slightly more negative 
towards using gender quotas than their male colleagues (both male immigrants and male non-immigrants). Feminist institutionalism and an understanding of how the political parties produce and include/exclude knowledge is important; female immigrant parliamentarians might be experiencing a 'double pressure', not only by a potential institutionalization of 'Swedishness' within the political parties but also by a hegemonic masculinity within political institutions, where there is a certain historical path dependency or structural stickiness, which treats masculinity as the norm and gender only refers to women.

Still two points need to be emphasized here; first of all, from an intersectionality perspective and the debate about politics of presence, it is highly problematic to perceive immigrants as a homogeneous group with common interests. Secondly, it is also problematic to perceive immigrant parliamentarians as automatic protectors of other immigrants instead of individuals with various ideological standpoints. This might deepen our understanding of the immigrant parliamentarians and their (potential) representative roles within their parties as well as how multiculturalism and ethnic diversity is made known and conceptualized within the two parties in question.

Accordingly, our first findings reveal that the number of immigrants in both parties does not reach the level of foreign-born Swedish citizens. The results from SVT's election compass 2014 indicate that immigrant parliamentarians do not automatically assimilate, they do make their voices known and in some areas their opinions appear to differ from the views of non-immigrant parliamentarians. Accordingly, we can cautiously claim that diversity is visible in both parties, which is in line with the ideologies of both parties. However, the diversity might be somewhat limited due to the fact that intersecting social factors, other than ethnicity, such as education, class and income, emphasize the commonalities between the immigrant parliamentarians and their non-immigrant colleagues rather than various immigrant groups in Swedish society that do not share these intersecting factors with the immigrant parliamentarians. Furthermore, the fact that there 
were barely any gender differences in the views of the immigrant parliamentarians might indicate that the political parties in question are path-dependent institutions, reproducing hegemonic masculinity, where gender only refers to women and the women adapt to an oppressive institutional environment. Further research is warranted in order to increase our understanding of how the political parties produce and include/exclude knowledge and organize power inequalities through formal as well as informal rules and practices.

\section{References}

Aftonbladet. 2014. 'Decemberöverenskommelsen' 29/12 2014 accessed March 2015 at: http://www.aftonbladet.se/tagg/2b19e3a1-935c4190-a44a-ff83be7d54d4.

Allern, Elin Haugsgjerd and Nicholas Aylott. 2009. 'Overcoming the Fear of Commitment: Pre-Electoral Coalitions in Norway and Sweden'. Acta Politica 44(1): 259-285.

Allern, Elin Haugsgjerd and Rune Karlsen. 2014. 'A Turn to the Right: The Norwegian Parliamentary Election of September 2013'. West European Politics (37)3: 653-663.

Aylott, Nicholas and Nicklas Bolin. 2015. 'Polarising Pluralism: The Swedish Parliamentary Election of September 2014'. West European Politics 38(3): 730-740.

Bergman, Torbjörn. 2000. 'Sweden: When Minority Cabinets Are the Rule and Majority Coalitions the Exception'. In Coalition Governments in Western Europe, edited by Wolfgang C. Müller and Kaare Strøm, 192230. Oxford: Oxford University Press.

Dahlberg, Anna. 2014. 'Alliansens Valtaktik Har Gått över Styr' ['The Electoral Tactics of the Alliance have Got Out of Hands']. Expressen. 26 April 2014.

Dahlerup, Drude. 2006. 'The Story of the Theory of Critical Mass'. Politics and Gender 2(4): 511-522.

Dahlerup, Drude and Lenita Freidenvall. 2010. 'Judging Gender Quotas. Predictions and Results'. Policy and Politics 38(3): 407-425.

DI-Dagens Industri. 2014. 'Efter kaosdagen- nu går Sverige mot nyval' 4/12 2014 accessed October 2016 at: http://www.di.se/artiklar/2014/ 12/3/efter-kaosdagen--nu-gar-sverige-mot-nyval/ 
Eriksson, Göran. 2016. 'SD-slalom mot normalisering'. Svenska dagbladet 14/2.2016, accessed March 2016 at: http://www.svd.se/sd-slalommot-normalisering

Erlingsson, Gissur, Karl Loxbo, and Richard Öhrvall. 2012. 'Anti-Immigrant Parties, Local Presence and Electoral Success'. Local Government Studies 38(6): 817-839.

Eurobarometer 82. 2014. 'Public Opinion in the European Union' by the European Commission. Accessed February 2015 at: http:/ / ec.europa.eu/public_opinion/archives/eb/eb82/eb82_first_e n.pdf .

Fredén, Annika. 2014. 'Threshold Insurance Voting in PR Systems: A Study of Voters' Strategic Behavior in the 2010 Swedish General Election'. Journal of Elections, Public Opinion and Parties 24(4): 473-492.

Freidenvall, Lenita and Mona Lena Krook. 2010. 'Discursive strategies for institutional Reform. Gender quotas in Sweden and France'. In Gender, Politics and Institutions. Towards a Feminist Institutionalism edited by Mona Lena Krook and Fioana MacKay, 42-57. Houndsmill, Basingstoke and Hampshire: Palgrave Macmillan.

Hagevi, Magnus. 2015. 'Bloc Identification in Multi-Party Systems: The Case of the Swedish Two-Bloc System'. West European Politics 38(1): 73-92.

Hellström, Anders. 2013. 'Varför vi älskar att hata Sverigedemokraterna'. Arkiv:Tidskrift för samhällsanalys 2.

Hellström, Anders. 2010. 'Det nya folkhemspartiet : populismens olika ansikten'. Fronesis 34: 100-124.

Hellström, Anders and Tom Nilsson. 2010. “We Are the Good Guys”: Ideological Positioning of the Nationalist Party Sverigedemokraterna in Contemporary Swedish Politics'. Ethnicities 10(1): 55-76.

Inhetveen, Katharina. 1999. 'Can Gender Equality Be Institutionalized? The Role of Launching Values in Institutional Innovation'. International Sociology. 14(4): 403-422.

Jónasdóttir, Anna. 1988. 'Sex/gender, power and politics: towards a theory of the foundations of male authority in the formally equal society'. Acta Sociologica 31(2): 157-174.

Jónasdóttir, Anna. and Jones, Kathleen. 2008. The political interests of gender revisited: Reconstructing feminist theory and political research. New York. UN University Press.

Kanter, Moss. 1977. Men and Women of the Corporation, New York: Basic Books.

Kenny, Meryl. 2007. 'Gender, Institutions and Power: A Critical Review'. Politics, 27(2):19-100. 
Krook, Mona Lena. 2009. Quotas for Women in Politics: Gender and Candidate Selection Reform Worldwide. London and New York: Oxford University Press.

Linderoth, Sam. 2015. 'V kräver att SL ändrar policy efter SD-reklamen'. ETC, 5/8 2015. Accessed August 2016 at: http:/ / www.etc.se/inrikes/v-kraver-att-sl-andrar-policy-efter-sdreklamen.

Lovenduski, Joni. 2005. State Feminism and Political Representation. Cambridge: Cambridge University Press.

Lovenduski, Joni. 2001. 'Women and Politics: Minority Representation or Critical Mass?'. Parliamentary Affairs 54(4): 743-758.

Magnusdottir, Gunnhildur Lily and Annica Kronsell. 2015. 'The in(visibility) of gender in Scandinavian climate policy-making.' International Feminist Journal of Politics 17(2): 308-326.

Magnusdottir, Gunnhildur Lily and Annica Kronsell. 2016. 'The Double Democratic Deficit in EU Climate-Policy-making by the European Commission.' Femina Politica- Special issue: 20 years since the Amsterdam Treaty: European Equality Policy Revisited 25(2): 64-77.

Mansbridge, Jane. 2003. 'Rethinking Representation'. American Political Science Review 97(4): 515-528.

Nagel, Joane. 2012. 'Intersecting identities and global climate change'. Global Studies in Culture and Power 19(4): 467-476.

Novus. 2014. 'Gapet mellan blocket halverat'. Accessed March 2016 at: http://novus.se/valjaropinionen/tv4novus-valjarbarometer/20142/tv4novus-valjarbarometer-8-september-2014-gapet-mellanblocken-halverat-2/

OECD. 2014. 'Indicators of integration- Sweden', accessed February 2015 at: http://www.oecd.org/migration/integrationindicators/keyindicato rsbycountry/name.218347.en.htm

Phillips, Anne. 2010. 'Representation and Inclusion'. Politics and Gender 8(4): 512-518.

Pierson, Paul. 2004. Politics in Time: History, Institutions, and Social Analysis. New Jersey: Princeton University Press.

Rosén, Hans. 2014. 'Reinfeldt: Öppna era hjärtan för de utsatta'. Dagens nyheter 16/8 2014. Accessed February 2015 at: http:/ / www.dn.se/valet-2014/ reinfeldt-oppna-era-hjartan-for-deutsatta/

Sannerstedt, Anders. 2014. 'Sverigedemokraternas Sympatisörer'. In Mittfåra $\mathcal{E}$ Marginal. SOM-Undersökningen 2013, edited by Annika Bergström and Henrik Oscarsson, 445-458. Gothenburg: SOM-institutet. 
Statistics Sweden- The Swedish Statistical Authority/Statistiska centralbyrån. Accessed February 2015 at: http://www.scb.se/sv_/Hitta-statistik/Artiklar/Fortsatt-okning-avutrikes-fodda-i-Sverige/

Svenska dagbladet. 2016. 'Invandring inte viktigast för väljare' 7/12 2016, accessed 12.12. 2016 at: http://www.svd.se/invandring-inteviktigast-for-valjare/om/sverige

SVT. 2014a. 'SVT Election compass-valkompassen 2014'. Accessed FebruaryApril 2015 at: www.svt.se/pejl/det-har-ar-valu

SVT. 2014b. 'Regeringskrisen: Detta händer nu' 3/12 2014. Accessed February 2015 at: http:/ / www.svt.se/nyheter/sverigedemokraternarostar-for-alliansens-budget-detta-hander-nu

The Swedish Election Authority (undated). Election Results. Accessed March 2015 at: http://www.val.se/val/val2014/slutresultat/R/rike/index. html

The Swedish Migration Agency/Migrationsverket accessed February 2015 at: http://www.migrationsinfo.se/migration/sverige/

The Swedish Parliament/Riksdagen. 2014. 'Ledamöter och partier'. Accessed March 2015 at: http://www.riksdagen.se/sv/ledamoterpartier/

Weldon. Laurel 2011. 'Perspectives Against Interests: Sketch of a Feminist Political Theory of Women'. Politics and Gender 7(3):441-446

Wängnerud, Lena. 2009. 'Women in Parliaments: Descriptive and Substantive Representation'. Annual Review of Political Science 12: 5169.

Wängnerud, Lena and Anders Sundell. 2012. 'Do politics matter? Women in Swedish local elected assemblies 1970-2010 and gender equality outcomes'. European Political Science Review 4(1): 97-120. 


\section{Appendix}

\section{Questions/proposals from The Election Compass of the Swedish National} Television

2014: SVT:S Vallokalsundersökning Riksdagsvalet 2014. Accessed in FebruaryApril 2015 at: www.svt.se/ pejl/det-har-ar-valu

Possible answers in the election compass [author's own translation]: a) Very positive, b) rather positive, c) rather negative, d) very negative, e) no opinion/indifferent

Question/proposal 1: 'Sweden should aim for a multicultural society'.

Question/proposal 2: 'Asylum seekers should be able to seek asylum in Swedish embassies abroad'.

Question/proposal 3: 'Sweden should aim for accepting fewer immigrants in the future'.

Question/proposal 4: 'The police should actively search for asylum seekers whose asylum applications have been rejected and the police should deport them'.

Question/proposal 5: 'Undocumented refugees should have access to free healthcare'.

Question/proposal 6: 'All municipalities should be obliged to accept refugees'.

Question/proposal 7: 'Gender quotas should be used in order to include more women as board members in companies'.

Question/proposal 8: 'Sweden should aim to redistribute power from men to women'. 